\title{
"The survival of business enterprises and access to finance: the case of 4 African countries"
}

\begin{tabular}{|c|c|}
\hline AUTHORS & $\begin{array}{l}\text { Yohannes Worku (D https://orcid.org/0000-0003-0482-6603 } \\
\text { R http://www.researcherid.com/rid/F-9255-2019 } \\
\text { Mammo Muchie (D https://orcid.org/0000-0003-4831-3113 }\end{array}$ \\
\hline ARTICLE INFO & $\begin{array}{l}\text { Yohannes Worku and Mammo Muchie (2019). The survival of business } \\
\text { enterprises and access to finance: the case of } 4 \text { African countries. Problems and } \\
\text { Perspectives in Management, 17(1), 326-338. doi:10.21511/ppm.17(1).2019.28 }\end{array}$ \\
\hline DOI & http://dx.doi.org/10.21511/ppm.17(1).2019.28 \\
\hline RELEASED ON & Tuesday, 26 March 2019 \\
\hline RECEIVED ON & Sunday, 06 January 2019 \\
\hline ACCEPTED ON & Thursday, 24 January 2019 \\
\hline LICENSE & $\begin{array}{l}(\mathrm{cc}) \mathrm{EY} \\
\text { This work is licensed under a Creative Commons Attribution } 4.0 \text { International } \\
\text { License }\end{array}$ \\
\hline JOURNAL & "Problems and Perspectives in Management" \\
\hline ISSN PRINT & $1727-7051$ \\
\hline ISSN ONLINE & $1810-5467$ \\
\hline PUBLISHER & LLC "Consulting Publishing Company "Business Perspectives" \\
\hline FOUNDER & LLC "Consulting Publishing Company "Business Perspectives" \\
\hline
\end{tabular}

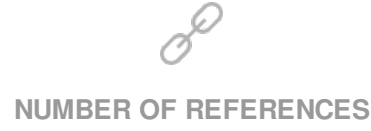

48
NUMBER OF FIGURES

1

\section{E=-}

NUMBER OF TABLES

11

(C) The author(s) 2022. This publication is an open access article. 


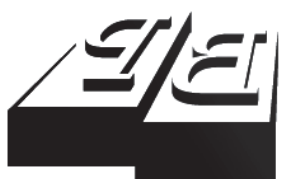

BUSINESS PERSPECTIVES

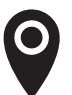

LLC "CPC "Business Perspectives" Hryhorii Skovoroda lane, 10, Sumy, 40022, Ukraine

www.businessperspectives.org

Received on: $6^{\text {th }}$ of January, 2018 Accepted on: $24^{\text {th }}$ of January, 2019

(C) Yohannes Worku,

Mammo Muchie, 2019

Yohannes Worku, Postdoctoral Fellow, Tshwane University of Technology, South Africa.

Mammo Muchie, Postdoctoral Fellow, Tshwane University of Technology, South Africa.

\section{THE SURVIVAL OF BUSINESS ENTERPRISES AND ACCESS TO FINANCE: THE CASE OF 4 AFRICAN COUNTRIES}

\begin{abstract}
Microfinance institutions render essential services to start-up small, micro, mediumsized enterprises (SMMEs) by way of extending loans to entrepreneurs. SMMEs operating in South Africa have relatively better access to microfinance loans in comparison with those operating in Nigeria, Kenya and Ethiopia. A survey was conducted in order to compare the relative ease of access to microfinance loans in South Africa, Nigeria, Kenya and Ethiopia based on a survey conducted in the four Sub-Saharan African countries. The ease of access to microfinance loans was assessed based on criteria defined by Barry and Tacneng (2014). A total of 401 SMMEs participated in the study. Loan applicants were asked to provide answers to questions that indicated the ease of securing loans and meeting loan repayment conditions. Emphasis was placed on the demand for collateral as a requirement for extending loans to applicants, the assessment of entrepreneurial and auditing skills of loan applicants, the difficulty of meeting loan repayment conditions, and adherence to regulations and guidelines recommended by governments. Descriptive, bivariate and multivariate methods of data analyses were used for data analyses. The study found that about $21 \%$ of SMMEs were satisfied with the ease of securing loans, whereas the remaining $79 \%$ of SMMEs did not. The ease of access to microfinance loans varied by country in which South African loan applicants were the most satisfied in comparison with the remaining three countries. Securing microfinance loans, as well as fulfilling loan repayment conditions were easiest in South Africa, and most difficult in Ethiopia. In terms of ease of securing loans and meeting loan repayment conditions, the order of nations was ranked as South Africa, Nigeria, Kenya and Ethiopia. In all four countries, the ease of access to microfinance loans was influenced by country of business operation, extent of benefits realized by SMMEs, and highest level of formal education.
\end{abstract}

\section{Keywords}

access to finance, survival, SMME, ordered probit regression

\section{JEL Classification D20, G21}

\section{INTRODUCTION AND BACKGROUND}

The main purpose of research was to critically examine the ease of borrowing loan from formally registered microfinance institutions in South Africa, Nigeria, Kenya and Ethiopia. Barry and Tacneng (2014) have defined criteria for determining the ease of borrowing loan from microfinance institutions. Although microfinance agencies are expected to complement services provided by commercial banks, they are characterized by financial inadequacy, lack of adherence to guidelines and policies issued by national governments, poor leadership, low ethical standards and poor professional standards. Microfinance agencies are expected to play a noble role by enabling SMMEs to bridge their immediate financial shortcomings. Chakrabarty and Bass (2013) have shown that microfinance agencies in developing nations such as South Africa, Nigeria, Kenya and Ethiopia often flout guidelines and operational policies. According to the authors, this limitation is attributed to lack of effective monitoring and evaluation mechanisms in 
all four nations. Okpara (2010) has cited two key causes of poor microfinance services in Sub-Saharan African nations such as Nigeria. These are failure to hold microfinance agencies accountable to licensing conditions and lack of financial capacity. In all three countries, microfinance institutions (MFIs) do not adhere strictly to guidelines that are recommended by national governments and central banks. As a result, entrepreneurs with the potential for sustained growth are denied access to credit by MFI institutions. Two motivating factors for the survey were the need for comparing the quality of microfinance services in the four African nations and the quest for reliable empirical evidence and scientific studies. Kemboi and Tarus (2013) have conducted a study in Kenya and have concluded that Kenyan SMMEs demand collateral and impose stringent loan repayment conditions on applicants. The authors have suggested practical remedial actions that require monitoring and evaluation from the Kenyan National Government. Regulation is required in order to ensure service quality standards, fairness and adequate compliance with relevant guidelines and regulations. The demand for improved and affordable microfinance services in South Africa, Nigeria, Kenya and Ethiopia is robust (Newman, Schwarz, \& Borgia, 2014). Jaffaris, Saleem, Abideen, Kaleem, Malik, and Raza (2011) have shown that microfinance institutions need to be strictly regulated and monitored as a means of ensuring fairness and objectivity in the disbursement of funds to SMMEs. The authors have argued that microfinance institutions must be monitored by regulating authorities and central banks in order to ensure satisfactory compliance with service standards. The goal of this research was to describe the strengths and weaknesses of microfinance services rendered by microfinance agencies operating in South Africa, Nigeria, Kenya and Ethiopia.

\section{LITERATURE REVIEW}

\subsection{South African SMMEs and access to finance}

The cost of borrowing money from microfinance institutions in South Africa is costly. The requirements for borrowing money from microfinance institutions as well as loan repayment conditions are also not easy to meet (Newman, Schwarz, \& Borgia, 2014). According to the authors, the key reasons are the demand for collateral, high service charges and high interest rates. The South African economy is a combination of first world and third world economies in which overall economic growth is often undermined due to massive unemployment, rural and urban poverty, poor municipal services, corruption, and lack of good governance (Rose-Ackerman \& Palifka, 2016). South Africans are heavily indebted with financial loans. The demand for microfinance loans and services among start-up enterprises is robust. In comparison with other African nations, South Africa has relatively well resourced and better managed microfinance agencies that render valuable services to entrepreneurs. Bazilian, Nakhooda, and Van de Graaf (2014) have reported that South Africans borrow money heavily for purchasing goods and services, and do not do well in terms of saving money in comparison with Japan, Malaysia, Singapore, South
Korea and China. Rose-Ackerman and Palifka (2016) have highlighted the strategic benefits of developing a culture of saving money by citing examples from countries such as Japan.

Since April 1994, new policies have been introduced in South Africa with a view to enable operators of SMMEs to have easy access to finance needed for conducting business and entrepreneurial activities. The support provided to microfinance agencies by the South African government is based on a strategic initiative taken by the South African government to grow and promote SMMEs that are owned and operated by black indigenous South Africans profitably. However, these institutions have failed to produce tangible results for the unemployed youth due to key obstacles such as difficulty in securing finance, acute shortage of entrepreneurial, technical, managerial, vocational and artisan skills, poor municipal service delivery, too much bureaucracy related to license applications and tax assessment, red tape, corruption, and lack of leadership and good governance (Edoho, 2015; Henrekson, 2014; Khale \& Worku, 2015; Worku, 2016). The above authors have called for the improvement of microfinance services extended to SMMEs. From the point of view of start-up SMMEs in South Africa, it is necessary to overcome two obstacles. These are granting easy access to loans and simplifying loan repayment conditions. 
According to Crane and Matten (2016), about 58\% of South Africans save money for an emergency. About $47 \%$ of South Africans save money as a provision in the event of death. About $41 \%$ of South Africans save money for funerals. Credit card holders have increased in number significantly since April 1994. A study conducted by Edoho (2015) shows that about 21 million South Africans have credit cards. Credit cards require regular repayment at relatively higher interest rates and additional service charges. However, South Africans depend heavily on credit cards. Crane and Matten (2016) have reported that about $74 \%$ of the credit market is serviced by formal banks and credit card companies, whereas stokvels and family and friends serve as source of credit to about $26 \%$ of South Africans.

\subsection{Nigerian SMMEs and access to finance}

In Nigeria, SMMEs play a key role in extending loans needed for economic development. This is done by way of generating employment opportunities for young graduates and by tackling the scourge of absolute poverty. SMMEs drive growth in GDP and create employments. SMMEs are valuable for the national economy, but cannot function optimally in the absence of loans. Filmer and Fox (2014) have cited difficulty in borrowing loan money by SMMEs operating in Nigeria's largest commercial cities such as Lagos. They have also stated that SMMEs are routinely exposed to unfavorable assessment by microfinance institutions in areas related to the demand for collateral and fixed assets as a requirement for the approval of loans from commercial banks and microfinance institutions. The situation in Kenya, Tanzania and Uganda is fairly similar to the situation observed in Nigeria (Julian \& Ofori-Dankwa, 2013). Kolk, Rivera-Santos, and Rufin (2014) have pointed out that the demand for collateral is the biggest obstacle to access to finance in Nigeria. Oni (2012) has argued that urban and rural people should be encouraged and supported to borrow money needed for development projects. The key problem has been the demand for collateral and fixed assets by commercial banks and microfinance institutions. Commercial banks and microfinance institutions in most Sub-Saharan African countries demand collateral and fixed assets before they approve loan money. It follows that start-up SMMEs often struggle to meet this stringent requirement for fixed as- sets. According to Haneef, Pramanik, Mohammed, and Muhammad (2014), the demand for collateral and fixed assets cannot be met by most newly established SMMEs. This fact calls for intervention by the national government with a view to ensure fairness and objectivity. Filmer and Fox (2014) have argued that microfinance institutions must be encouraged to lend out money to the unemployed youth as a means of helping them to get a livelihood. The authors have pointed out that a critical aspect of such help would be to provide skills-based training programs to all beneficiaries of such youth development programs. Fosu (2015) points out that such development and assistance programs must be accompanied with strict monitoring and evaluation programs and mechanisms. Guerin, Morvant-Roux, and Villarreal (2013) have provided an example from the USA in which strict monitoring and evaluation programs have minimized default rates among borrowers. Cramm and Nieboer (2011) have outlined norms and standards for efficient microfinance services in Sub-Saharan African countries. Bruton, Ketchen, and Ireland (2013) have listed down key obstacles such as collateral requirements and a track record of profitability by microfinance institutions and commercial banks in Sub-Saharan African countries.

Biosca, Lenton, and Mosley (2014) have argued that microfinance services should be modelled after what has been done by the Grameen Bank of Bangladesh. The model from Bangladesh has successfully alleviated abject poverty among unemployed rural women. The key to the success achieved in Bangladesh is the provision of loan guarantee by the national government. The other equally important success factor in Bangladesh is Grameen Bank's dedicated service in assessing, evaluating, monitoring and controlling the disbursement and recovery of loan money extended to SMMEs and various applicants such as community-based associations. The big role players in Nigeria are the Nigerian Ministry of Finance, the Nigerian Central Bank, various Nigerian commercial banks and the Stock Exchange of Nigeria. In addition to the formal sector, the informal sector also extends microfinance services to operators of SMMEs in manners that suit lenders and borrowers. There is enough demand for both formal and informal loan services. However, it is not so easy to regulate and monitor the ease of securing loan money from informal microfinance service providers. The ease of access to loan money from informal microf- 
inance agencies varies depending on residential area (rural or urban), economic sector, the financial capacity of microfinance service providers, and the degree to which regulations are enforced by the Nigerian government.

\subsection{Kenyan SMMEs and access to finance}

In Kenya, microfinance institutions play a major role in the national economy by making finance available to aspiring entrepreneurs and innovative young graduates of vocational schools, technical colleges and universities. Microfinance agencies operating in Kenyan cities and towns are routinely used for securing loans. Wijesiri and Meoli (2015) have stated that it is not easy to determine the percentage of money borrowed from microfinance agencies that is utilized according to approved plans of action. Kenyan microfinance agencies assist start-up SMMEs by granting them with fast and easy money required for business operation. Since Kenya declared independence from Britain in May 1963, microfinance agencies have played a major role in the Kenyan economy along with commercial banks and insurance companies. Microfinance agencies have taken credit for alleviating poverty among men and women, as well as the unemployed youth. According to the Kenyan government, poor and unemployed Kenyans can improve their low socioeconomic status by taking microfinance. The key problem in Kenya has been lack of capacity among microfinance institutions. Examples of some of the key obstacles are lack of capacity, improper regulations, inability to enforce the law, stiff competition with commercial banks, failure to produce innovative and diversified products, lack of profitability, lack of stability, and lack of monitoring and evaluating services to microfinance institutions (MFIs).

Wijesiri and Meoli (2015) have shown that formal money lending institutions, as well as traditional microfinance agencies such as commercial banks, Equity Bank of Kenya, K-Rep Bank of Kenya, Family Bank of Kenya, the Co-operative Bank of Kenya, Faulu Bank of Kenya, Finance Trust Bank of Women of Kenya, SMEP Bank of Kenya, Kadet Bank of Kenya and Jamii Bora Bank of Kenya, provide loans to operators of SMMEs. However, the loan criteria imposed on SMMEs by lenders such as ordinary commercial banks is quite stringent. According to the authors, the key obstacle is the demand for collateral and a proven track record of paying back loans. The relatively higher interest rates imposed by microfinance agencies and stringent loan repayment conditions are a major deterrent to SMMEs. Microfinance agencies operating in Kenya are ranked as the best in the entire East African region according to studies conducted by Segun and Anjugam (2013). The study conducted by Taiwo, Onasanya, Yewande, Edwin, and Benson (2016) has shown that Kenyan microfinance institutions provide a relatively more significant assistance to SMMEs operating in Kenya in comparison with commercial banks, although microfinance agencies are relatively costlier in terms of interest rates. The study conducted by Sila (2014) has shown that microfinance institutions have managed to provide badly needed loan services to Kenyan women who conduct entrepreneurial activities in the eastern Nyanza region of Kenya.

Kenya is home to several microfinance agencies that offer loan services to operators of SMMEs in almost all economic sectors. In the East African region, Kenyan microfinance agencies provide the best and most professional loan services to operators of SMMEs (Siwale \& Ritchie, 2012; Roitch, Lagat, \& Kogel, 2015). The authors have shown that Kenyan microfinance institutions have the largest capacity in the East African region in comparison with other East African economies. The study conducted by Schwitay (2014) has found that there are 25 large microfinance institutions in Kenya that extend loans to SMMEs to the tune of about 2 billion American Dollars to about 2 million operators of SMMEs. Shisia, Marangu, and Omwario (2014) have pointed out that the Equity Bank of Kenya controls about $74 \%$ of the microfinance market in Kenya. The Equity Bank of Kenya has about 716,000 active customers in its database. The Kenya Women Microfinance Bank has a market share of about $12 \%$ and about 334,000 customers. K-Rep Bank has a market share of 6.39\% and about 82,000 active customers. The microfinance company FAULU has a market share of about $4 \%$ and about 102,000 active customers. The Kenyan microfinance company Jamii Bora has a market share of about $1 \%$ and about 80,000 customers. The company Kenya Women Finance Trust (KWIFT) provides loans to about 334,000 customers.

Rottenburg, Merry, Park, and Mugler (2015) have provided practical examples in which Kenyan mi- 
crofinance agencies play a vital part in building and growing the national economy of Kenya. The key methods are providing loan money needed for business activities, education, medical treatment, construction, agriculture, and construction projects. They also extend personal and emergency loans, although such loans are provided at very high interest rates and stringent loan repayment conditions (Mori, Golesorkhi, Randoy, \& Hermes, 2015). Kenyan microfinance institutions offer loan services to individual applicants, as well as groups of applicants. A group could have between 2 and 30 members. Loan services are extended to both men and women. Examples of microfinance agencies that extend loan services to the majority of Kenyans are the Equity Bank of Kenya, K-Rep Bank and Jamii Bora (Rolffs, Ockwell, \& Byrne, 2015). This shows that Kenyan microfinance institutions provide loans to individuals, as well as groups of entrepreneurs.

According to Otieno and Moronge (2014), microfinance agencies in Kenya have failed to exploit the education section of the economy fully to their own advantage. They are quite reluctant to lend money to applicants who seek loan services. Musamali and Tarus (2013) have pointed out that microfinance agencies are heavily involved in the services sector of the economy, and that they are only marginally interested in the education sector for financial reasons. The microfinance agency KADET has only 220 customers. The microfinance agency ECLOF has only 211 customers. The microfinance agency SISDO has only 202 customers. The agency Adok Timo has only 173 customers. Nega and Schneider (2014) have pointed out that about $35 \%$ of Kenyans have difficulty in securing loans at affordable rates, mostly due to high interest rates imposed on loans by microfinance institutions. The authors have pointed out that about $30 \%$ of Kenyans have no access to banking services. Most of these Kenyans live in rural areas.

\subsection{Ethiopian SMMEs and access to finance}

Since the early 1990s, microfinance agencies have been providing loan money needed by start-up entrepreneurs in Ethiopia. The administration of microfinance agencies is regulated by an act issued by the Ethiopian government in 1996 (Brautigam \& Gallagher, 2014). The total number of duly registered microfinance agencies in Ethiopia is less than 50 (Banerjee, Duflo, Goldberg, Karlan, Osei, Pariente, Shapiro, Thuysbaert, \& Udry, 2015). The degree of competition among microfinance agencies is low in comparison with the degree of competition in countries such as South Africa, Nigeria and Kenya (Abate, Borzaga, \& Getnet, 2014). The largest microfinance agencies in Ethiopia are the Amhara Credit and Saving Institution (ACSI), Dedebit Credit and Savings Institution (DECSI), Oromia Credit and Savings Share Company (OCSSCO), Addis Savings and Credit Institution (ADSCI) and Omo Microfinance Institution Share Company (Bassem, 2014). The largest microfinance agencies work closely with the National Bank of Ethiopia (NBE). The total capital and total asset of microfinance agencies in Ethiopia was about 200 million American Dollars and 800 million American Dollars, respectively (Banerjee, Karlan, \& Zinman, 2015).

Only four microfinance agencies offer loans to $75 \%$ of all applicants. Half of all microfinance agencies are located in Addis Ababa. This fact shows that microfinance services are available mostly to urban applicants only (Mersland \& Strom, 2014). Microfinance agencies operating in Addis Ababa account for $40 \%$ of the total number of microfinance loans provided by the 30 microfinance agencies in Ethiopia to only $5 \%$ of the Ethiopian population. In the Tigray region, $40 \%$ of all loans provided by the sector is provided to $5 \%$ of the population of Ethiopia. In the Amhara region, $16 \%$ of all loans provided by the sector is provided to $20 \%$ of the population of Ethiopia. In the Oromo region, 16\% of all loans provided by the sector is provided to $20 \%$ of the population of Ethiopia (Nega \& Schneider, 2014). Microfinance agencies in Ethiopia are significantly smaller and poorly resourced in comparison with microfinance agencies in South Africa, Nigeria and Kenya. Microfinance agencies in Kenya are at least four times better equipped and adequately resourced in comparison with those in Ethiopia (Page \& Soderbom, 2015). The key shortcoming of microfinance agencies in Ethiopia is that they demand collaterals and fixed assets from applicants (Ayele, 2015). They also impose stringent loan repayment conditions on applicants. Furthermore, their lending capacities are quite poor (E. Worku \& Z. Worku, 2008). 


\section{METHODS AND DATA}

An exploratory, descriptive and cross-sectional study design was utilized for conducting the research. In the months of October, November and December 2017, data were collected from a stratified random sample of 401 SMMEs for the study (154 from South Africa, 132 from Nigeria, 88 from Kenya, and 27 from Ethiopia). Data were collected by a postdoctoral research fellow working at Tshwane University of Technology in Pretoria, South Africa as part of the study. Participants of the research were asked to complete a structured and self-administered questionnaire of study in which information was collected on 35 socioeconomic factors. The ease of access to loans was measured by the standards of Barry and Tacneng (2014) set out for assessing microfinance-related activities of interest to SMMEs. The analyses of raw data sets were performed by utilizing frequency tables, cross tabulated tests of associations, ordered probit regression and factor analysis (Chatterjee \& Hadi, 2015).

The paper aims to construct a framework that could be used for improving the quality of services provided to businesses by microfinance institutions operating in South Africa, Nigeria, Kenya and Ethiopia.

\section{RESULTS}

Based on the criteria set out by Barry and Tacneng (2014), the results showed that 76 of the 401 SMMEs in the survey $(18.95 \%)$ had a positive perception about microfinance services. The remaining 325 participants $(81.05 \%)$ had a negative perception. Participants were selected from South Africa $(38.40 \%)$, Nigeria (32.92\%), Kenya (21.95\%) and Ethiopia (6.73\%). About 55\% of participants had solely owned SMMEs. About 34\% of participants were in the general services sector. Trade and commerce accounted for about $25 \%$ of participants.

Partnerships accounted for about $25 \%$ of participants. About $57 \%$ of participants were in distribution and sales. About $76 \%$ of participants were male. About $47 \%$ of participants had age of 31 to 40 years. About $32 \%$ of participants had age of 20 to 30 years. The percentage of participants who had completed secondary school level education was about $44 \%$. The percentage of participants with Bachelor's degrees was about $16 \%$.
Table 1. General characteristics of participants of study $(n=401)$

\begin{tabular}{|c|c|}
\hline Variable of study & Frequency (percentage) \\
\hline \multirow{2}{*}{$\begin{array}{l}\text { Perception on } \\
\text { the quality of } \\
\text { microfinance } \\
\text { services provided } \\
\text { to SMMEs }\end{array}$} & Positive: 76 (18.95\%) \\
\hline & Negative: 325 (81.05\%) \\
\hline \multirow{4}{*}{$\begin{array}{l}\text { Country of } \\
\text { business operation }\end{array}$} & South Africa: 154 (38.40\%) \\
\hline & Nigeria: $132(32.92 \%)$ \\
\hline & Kenya: 88 (21.95\%) \\
\hline & Ethiopia: $27(6.73 \%)$ \\
\hline \multirow{6}{*}{$\begin{array}{l}\text { Economic sector of } \\
\text { SMME }\end{array}$} & Agriculture and mining: 107 (26.68\%) \\
\hline & Manufacturing: 21 (5.24\%) \\
\hline & Oil and gas: $19(4.74 \%)$ \\
\hline & General services: $135(33.67 \%)$ \\
\hline & Trade and commerce: $101(25.19 \%)$ \\
\hline & Others: $18(4.49 \%)$ \\
\hline \multirow{4}{*}{$\begin{array}{l}\text { Type of business } \\
\text { activity }\end{array}$} & Franchise: 38 (9.48\%) \\
\hline & Solely owned: $221(55.11 \%)$ \\
\hline & Partnership: 102 (25.44\%) \\
\hline & Others: $40(9.98 \%)$ \\
\hline \multirow{4}{*}{$\begin{array}{l}\text { Economic sector of } \\
\text { SMME }\end{array}$} & Consulting: $69(17.21 \%)$ \\
\hline & Distribution and sales: $229(57.11 \%)$ \\
\hline & Production: 76 (18.95\%) \\
\hline & Others: $27(6.73 \%)$ \\
\hline \multirow{2}{*}{$\begin{array}{l}\text { Gender of } \\
\text { respondent }\end{array}$} & Male: $304(75.81 \%)$ \\
\hline & Female: $97(24.19 \%)$ \\
\hline \multirow{5}{*}{$\begin{array}{l}\text { Age category of } \\
\text { respondent }\end{array}$} & Below 20 years: $42(10.47 \%)$ \\
\hline & 20 to 30 years: $127(31.67 \%)$ \\
\hline & 31 to 40 years: $188(46.88 \%)$ \\
\hline & 41 to 50 years: $26(6.48 \%)$ \\
\hline & 51 years or more: $18(4.49 \%)$ \\
\hline \multirow{6}{*}{$\begin{array}{l}\text { Highest level of } \\
\text { formal education }\end{array}$} & Primary level or less: $52(12.97 \%)$ \\
\hline & Secondary level: 178 (44.39\%) \\
\hline & Certificate: $60(14.96 \%)$ \\
\hline & Diploma: $41(10.22 \%)$ \\
\hline & Bachelor's degree: 64 (15.96\%) \\
\hline & Master's degree or above: $6(1.50 \%)$ \\
\hline
\end{tabular}

Table 2 shows figures for business-related characteristics. About $55 \%$ of businesses had operated for three to five years at the time of the study. About 25\% of businesses had operated for six years or longer at the time of the study. The percentage of businesses that were owned by a single operator was about $60 \%$. Family or group ownership accounted for about $27 \%$. Shareholding accounted for about $12 \%$. The percentage of businesses in the wholesale or retail sector was about $62 \%$. About $72 \%$ of businesses employed five or fewer employees in their businesses. 
Table 2. Duration of operation of businesses $(n=401)$

\begin{tabular}{|c|c|}
\hline Variable of study & Frequency (percentage) \\
\hline \multirow{4}{*}{$\begin{array}{l}\text { Duration of operation } \\
\text { of business }\end{array}$} & Less than a year: $19(4.74 \%)$ \\
\hline & One to two years: $58(14.46 \%)$ \\
\hline & Three to five years: $222(55.36 \%)$ \\
\hline & Six years or more: $102(25.44 \%)$ \\
\hline \multirow{4}{*}{$\begin{array}{l}\text { Type of ownership of } \\
\text { business }\end{array}$} & A single owner: $239(59.60 \%)$ \\
\hline & Family or group: $109(27.18 \%)$ \\
\hline & Shareholders: $47(11.72 \%)$ \\
\hline & Others: $6(1.50 \%)$ \\
\hline \multirow{4}{*}{$\begin{array}{l}\text { Type of business } \\
\text { activity conducted }\end{array}$} & Agriculture: $81(20.20 \%)$ \\
\hline & Manufacturing: 56 (13.97\%) \\
\hline & Wholesale or retail: $250(62.34 \%)$ \\
\hline & Others: $14(3.49 \%)$ \\
\hline \multirow{3}{*}{$\begin{array}{l}\text { Number of employees } \\
\text { employed by SMME }\end{array}$} & Five or fewer: 289 (72.07\%) \\
\hline & Five to twenty: $81(20.20 \%)$ \\
\hline & Twenty one or more: 31 (7.73\%) \\
\hline
\end{tabular}

Table 3 shows turnover money produced by businesses in the survey. About $72 \%$ of businesses could only produce a turnover of R500,000 or less. Only $13 \%$ of businesses were capable of producing a turnover of between R 5 million and R10 million. Profitability was undermined by lack of capital in about $62 \%$ of businesses. About $9 \%$ of participants used loan money taken from microfinance agencies for business expansion. About $43 \%$ of participants used loan money borrowed from microfinance agencies for ordering merchandise.

Table 3. Turnover generated by businesses $(n=401)$

\begin{tabular}{|c|c|}
\hline Variable of study & Frequency (percentage) \\
\hline \multirow{4}{*}{$\begin{array}{l}\text { Turnover generated } \\
\text { by business }\end{array}$} & R500,000 or less: $289(72.07 \%)$ \\
\hline & R500,001 to R1,000,000: 32 (7.98\%) \\
\hline & R1,000,001 to R5,000,000: 27 (6.73\%) \\
\hline & $\begin{array}{l}\text { R5,000,001 to R10,000,000: } 53 \\
(13.22 \%)\end{array}$ \\
\hline \multirow{4}{*}{$\begin{array}{l}\text { Factors that } \\
\text { undermine } \\
\text { profitability }\end{array}$} & High cost of rental: $59(14.71 \%)$ \\
\hline & Lack of capital: $250(62.34 \%)$ \\
\hline & Wrong location: $55(13.72 \%)$ \\
\hline & Poor demand: $37(9.23 \%)$ \\
\hline \multirow{6}{*}{$\begin{array}{l}\text { Purpose for which } \\
\text { loan taken from } \\
\text { microfinance } \\
\text { institutions is used } \\
\text { by businesses }\end{array}$} & $\begin{array}{l}\text { Training and capacity building: } 23 \\
(5.74 \%)\end{array}$ \\
\hline & Goods and services: 48 (11.97\%) \\
\hline & Business expansion: $38(9.48 \%)$ \\
\hline & Ordering merchandise: 174 (43.39\%) \\
\hline & Paying municipal bills: 21 (5.24\%) \\
\hline & Others: 97 (24.19\%) \\
\hline
\end{tabular}

Table 4 quantifies the key difficulties and benefits associated with loans. For about $23 \%$ of applicants, the task of securing a loan from microfinance agencies was extremely difficult. For about $54 \%$ of applicants, the task was harder than expected. About $46 \%$ of participants indicated that they managed to improve their investment and production capacities by taking loan money from microfinance agencies. About $40 \%$ of participants indicated that the amount of profit realized by taking a loan from microfinance agencies was less than expected.

Table 4. Difficulties and benefits associated with loans $(n=401)$

\begin{tabular}{|c|c|}
\hline Variable of study & Frequency (percentage) \\
\hline \multirow{5}{*}{$\begin{array}{l}\text { Extent of problems } \\
\text { experienced while applying } \\
\text { for loans }\end{array}$} & As expected: $48(11.97 \%)$ \\
\hline & $\begin{array}{l}\text { Easier than expected: } 34 \\
(8.48 \%)\end{array}$ \\
\hline & $\begin{array}{l}\text { Harder than expected: } 218 \\
(54.36 \%)\end{array}$ \\
\hline & Not difficult at all: $7(1.75 \%)$ \\
\hline & $\begin{array}{l}\text { Extremely difficult: } 94 \\
(23.44 \%)\end{array}$ \\
\hline \multirow{5}{*}{$\begin{array}{l}\text { Description of benefit } \\
\text { achieved by business after } \\
\text { taking loan }\end{array}$} & $\begin{array}{l}\text { Growth in innovation: } 27 \\
(6.73 \%)\end{array}$ \\
\hline & $\begin{array}{l}\text { Growth in capital base: } 125 \\
(31.17 \%)\end{array}$ \\
\hline & $\begin{array}{l}\text { More competitive business: } \\
59(14.71 \%)\end{array}$ \\
\hline & $\begin{array}{l}\text { Improved investment and } \\
\text { production capacity: } 185 \\
(46.13 \%)\end{array}$ \\
\hline & Other benefits: $5(1.25 \%)$ \\
\hline \multirow{5}{*}{$\begin{array}{l}\text { Extent of profit realized by } \\
\text { business after taking loan }\end{array}$} & As expected: $56(13.97 \%)$ \\
\hline & $\begin{array}{l}\text { Less than expected: } 159 \\
(39.65 \%)\end{array}$ \\
\hline & $\begin{array}{l}\text { More than expected: } 37 \\
(9.23 \%)\end{array}$ \\
\hline & Extremely low: 115 (28.69\%) \\
\hline & Extremely high: 34 (8.48\%) \\
\hline
\end{tabular}

Table 5 quantifies the task of meeting key requirements for loan approval by microfinance agencies. The table shows that only $23 \%$ of applicants managed to meet the demand for collateral easily enough. For about $43 \%$ of applicants, the task of collateral constituted a major difficulty. Showing proof of fixed assets was a major problem for about $36 \%$ of applicants for a loan. Showing proof of current audit report was a major problem for about $49 \%$ of applicants for a loan. Showing proof of tax compliance was a major problem for about $47 \%$ of applicants for a loan. Showing proof of valid trading license was a major problem for about $6 \%$ of applicants for a loan. 
Table 5. Assessment of difficulties in meeting requirements for loans $(n=401)$

\begin{tabular}{|c|c|}
\hline $\begin{array}{c}\text { Requirement for } \\
\text { loan }\end{array}$ & Frequency (percentage) \\
\hline \multirow{5}{*}{ Proof of collateral } & Easily enough: $93(23.19 \%)$ \\
\hline & Fairly well: 31 (7.73\%) \\
\hline & As expected: $92(22.94 \%)$ \\
\hline & With minor difficulties: 14 (3.49\%) \\
\hline & With major difficulties: 171 (42.64\%) \\
\hline \multirow{5}{*}{ Proof of fixed assets } & Easily enough: $65(16.21 \%)$ \\
\hline & Fairly well: $43(10.72 \%)$ \\
\hline & As expected: 80 (19.95\%) \\
\hline & With minor difficulties: $69(17.21 \%)$ \\
\hline & With major difficulties: 144 (35.91\%) \\
\hline \multirow{5}{*}{$\begin{array}{l}\text { Proof of current } \\
\text { audit report }\end{array}$} & Easily enough: $41(10.22 \%)$ \\
\hline & Fairly well: $57(14.21 \%)$ \\
\hline & As expected: $87(21.70 \%)$ \\
\hline & With minor difficulties: $19(4.74 \%)$ \\
\hline & With major difficulties: 197 (49.13\%) \\
\hline \multirow{5}{*}{$\begin{array}{l}\text { Proof of steady } \\
\text { income }\end{array}$} & Easily enough: $13(3.24 \%)$ \\
\hline & Fairly well: $50(12.47 \%)$ \\
\hline & As expected: $102(25.44 \%)$ \\
\hline & With minor difficulties: 9 (2.24\%) \\
\hline & With major difficulties: 227 (56.61\%) \\
\hline \multirow{5}{*}{$\begin{array}{l}\text { Proof of tax } \\
\text { compliance }\end{array}$} & Easily enough: $44(10.97 \%)$ \\
\hline & Fairly well: $39(9.73 \%)$ \\
\hline & As expected: $102(25.44 \%)$ \\
\hline & With minor difficulties: $27(6.73 \%)$ \\
\hline & With major difficulties: 189 (47.13\%) \\
\hline \multirow{5}{*}{$\begin{array}{l}\text { Proof of valid trading } \\
\text { license }\end{array}$} & Easily enough: $113(28.18 \%)$ \\
\hline & Fairly well: $49(12.22 \%)$ \\
\hline & As expected: $12(2.99 \%)$ \\
\hline & With minor difficulties: $201(50.12 \%)$ \\
\hline & With major difficulties: $26(6.48 \%)$ \\
\hline
\end{tabular}

Table 6 shows frequency counts and percentages on defaulting on loans taken from microfinance institutions. The table shows that about $49 \%$ of applicants defaulted on loan repayments at least once in the past.

Table 6. Defaulting on loans taken from microfinance institutions $(n=401)$

\begin{tabular}{l:c}
\hline Variable of study & Frequency (percentage) \\
\hline $\begin{array}{l}\text { Experience of } \\
\text { defaulting on loan } \\
\text { repayment at least } \\
\text { once in the past }\end{array}$ & Defaulted at least once: $198(49.38 \%)$ \\
\hdashline & Never defaulted: $203(50.62 \%)$ \\
$\begin{array}{l}\text { Experience of } \\
\text { bankruptcy at least } \\
\text { once in the past }\end{array}$ & Nevkrupt at least once: $187(46.63 \%)$ \\
\hline
\end{tabular}

Table 6 (cont.). Defaulting on loans taken from microfinance institutions $(n=401)$

\begin{tabular}{|c|c|}
\hline Variable of study & Frequency (percentage) \\
\hline \multirow{3}{*}{$\begin{array}{l}\text { Preferred choice for } \\
\text { loan application }\end{array}$} & Commercial bank: $126(31.42 \%)$ \\
\hline & Microfinance institution: $178(44.39 \%)$ \\
\hline & Others: $97(24.19 \%)$ \\
\hline \multirow{2}{*}{$\begin{array}{l}\text { Ability to draw up a } \\
\text { business plan }\end{array}$} & Yes: $242(60.35 \%)$ \\
\hline & No: $159(39.65 \%)$ \\
\hline \multirow{2}{*}{$\begin{array}{l}\text { Perception on how } \\
\text { helpful microfinance } \\
\text { institutions are for } \\
\text { SMMEs }\end{array}$} & Helpful: 181 (45.14\%) \\
\hline & Not helpful: $220(54.86 \%)$ \\
\hline
\end{tabular}

Table 7 shows frequency counts and percentages for ways and means in which national governments can assist SMMEs. It can be seen from the table that valuable suggestions were made by operators of SMMEs. The most popular suggestion was that Central or Reserve Banks in South Africa, Nigeria, Kenya and Ethiopia should be enforcing regulations on microfinance institutions and loan applications by SMMEs with enough vigor (38\%). The second most popular suggestion was that trade restrictions, heavy bureaucracy and red tape should be eased (35\%). The third most popular suggestion was a call for training (13\%). The fourth most popular suggestion was that tax waiver should be granted to start-up and newly established businesses at their infant stages (7\%). The fifth most popular suggestion was that there must be a policy on promoting local content and diversity of business operations (6\%).

Table 7. Ways and means in which national government can assist SMMEs $(n=374)$

\begin{tabular}{|c|c|}
\hline Variable of study & $\begin{array}{l}\text { Frequency } \\
\text { (percentage) }\end{array}$ \\
\hline $\begin{array}{l}\text { Central or Reserve Banks in South Africa, } \\
\text { Nigeria, Kenya and Ethiopia should be } \\
\text { enforcing regulations on microfinance } \\
\text { institutions and loan applications by } \\
\text { SMMEs with enough vigor }\end{array}$ & $154(38.40 \%)$ \\
\hline $\begin{array}{l}\text { Trade restrictions, heavy bureaucracy } \\
\text { and red tape should be eased }\end{array}$ & $141(35.16 \%)$ \\
\hline $\begin{array}{l}\text { Training should be provided to SMMEs } \\
\text { with adequate monitoring and evaluation } \\
\text { mechanisms }\end{array}$ & $53(13.22 \%)$ \\
\hline $\begin{array}{l}\text { Tax waiver should be granted to start-up } \\
\text { and newly established businesses at their } \\
\text { infant stages }\end{array}$ & $27(6.73 \%)$ \\
\hline $\begin{array}{l}\text { There must be a policy on promoting } \\
\text { local content and diversity of business } \\
\text { operations }\end{array}$ & $26(6.48 \%)$ \\
\hline
\end{tabular}

Table 8 shows significant results obtained from crosstab tests. 
Table 8. Significant bivariate interactions $(n=401)$

\begin{tabular}{|c|c|c|}
\hline $\begin{array}{c}\text { Factors that determine } \\
\text { efficiency in microfinance } \\
\text { services }\end{array}$ & $\begin{array}{l}\text { Observed Chi- } \\
\text { square value }\end{array}$ & p-value \\
\hline Country of operation & 54.09 & 0.000 \\
\hline Duration of service & 51.66 & 0.000 \\
\hline $\begin{array}{l}\text { Perception on benefits realized } \\
\text { by SMMEs from microfinance } \\
\text { institutions }\end{array}$ & 48.37 & 0.000 \\
\hline Highest level of education & 40.09 & 0.000 \\
\hline Past history of bankruptcy & 35.55 & 0.000 \\
\hline $\begin{array}{l}\text { Extent to which business has } \\
\text { improved by taking loan }\end{array}$ & 32.11 & 0.000 \\
\hline $\begin{array}{l}\text { Extent of difficulty in securing } \\
\text { loan }\end{array}$ & 21.12 & 0.000 \\
\hline $\begin{array}{l}\text { Ability to meet requirements } \\
\text { for securing loan }\end{array}$ & 19.99 & 0.000 \\
\hline Year of registration & 17.08 & 0.000 \\
\hline
\end{tabular}

Bivariate analysis showed that 9 of the variables of study were highly significant predictors of efficiency in microfinance institutions. The $p$-values were equal to 0.000 for all 9 variables of study. These were: country of operation, duration of service, perception on benefits of microfinance institutions, highest level of education, past history of bankruptcy, extent to which business has improved by taking loan, extent of difficulty in securing loan, ability to meet requirements for securing loan, and year of registration. Table 9 shows regression coefficients from ordered probit regression along with $p$-values and $95 \%$ confidence intervals.

Table 9. Ordered probit regression coefficients

\begin{tabular}{l|c|c}
\hline \multicolumn{1}{c|}{ Factor } & p-value & $\begin{array}{c}\text { Coefficients and } \\
\text { 95\% confidence } \\
\text { intervals }\end{array}$ \\
\hline $\begin{array}{l}\text { Country of business } \\
\text { operation }\end{array}$ & 0.000 & $4.11(2.91,7.44)$ \\
\hline $\begin{array}{l}\text { The perception that } \\
\text { the benefits realized } \\
\text { by SMMEs from } \\
\text { microfinance institutions } \\
\text { are insignificant }\end{array}$ & 0.000 & $3.88(2.43,6.46)$ \\
\hline $\begin{array}{l}\text { Low level of formal } \\
\text { education }\end{array}$ & 0.000 & $2.73(1.86,5.79)$ \\
\hline
\end{tabular}

Results of data analysis obtained from ordered probit regression analysis showed that 3 of the 9 variables of study were highly significant predictors of the ability of microfinance institutions to provide efficient services to operators of SMMEs. These were Country of business operation, Extent of benefits realized by SMMEs, and Highest level of formal education. Additional data analysis was done by using log linear analysis (DeFusco, McLeavey, Pinto, Anson, \& Runkle, 2015). Table 10 shows two-by-two interactions that influence the adequacy of microfinance services rendered to entrepreneurs in South Africa, Nigeria, Kenya and Ethiopia.

Table 10. Significant two-by-two associations

\begin{tabular}{l|c}
\hline \multicolumn{1}{c}{$\begin{array}{c}\text { Factors associated with inadequate } \\
\text { microfinance services }\end{array}$} & p-value \\
\hline Country of business operation & 0.0000 \\
\hline $\begin{array}{l}\text { The perception that the benefits realized by } \\
\text { SMMEs from microfinance institutions are } \\
\text { insignificant }\end{array}$ & 0.0000 \\
\hline Low level of formal education & 0.0000 \\
\hline
\end{tabular}

The results in Table 10 show that the provision of poor microfinance services to SMMEs is significantly associated with country of business operation, the perception that the benefits realized by SMMEs from microfinance institutions are insignificant, and low level of formal education. Table 11 shows extracted factors and eigenvalues.

Table 11. Extracted factors and eigenvalues

\begin{tabular}{|c|c|c|c|}
\hline Extracted factor & Eigenvalue & $\begin{array}{c}\text { Percentage } \\
\text { of explained } \\
\text { variance in } \\
\text { viability }\end{array}$ & $\begin{array}{c}\text { Cumulative } \\
\text { percentage } \\
\text { of explained } \\
\text { variance }\end{array}$ \\
\hline $\begin{array}{l}\text { Country of } \\
\text { operation }\end{array}$ & 2.809 & 31.359 & 31.359 \\
\hline $\begin{array}{l}\text { Duration of } \\
\text { service }\end{array}$ & 2.746 & 24.172 & 55.531 \\
\hline $\begin{array}{l}\text { Perception on } \\
\text { benefits realized } \\
\text { by SMMEs from } \\
\text { microfinance } \\
\text { institutions }\end{array}$ & 2.635 & 12.505 & 68.081 \\
\hline $\begin{array}{l}\text { Highest level of } \\
\text { education }\end{array}$ & 2.557 & 10.228 & 78.309 \\
\hline $\begin{array}{l}\text { Past history of } \\
\text { bankruptcy }\end{array}$ & 2.419 & 6.331 & 84.640 \\
\hline
\end{tabular}

The factors extracted above indicate that the adequacy of microfinance services is dependent upon the same set of factors indicated in Table 10.

The key finding of study is that microfinance agencies need to be closely supported, monitored and evaluated in order to ensure adequate compliance with government regulations, and to protect vital attributes such as fairness, objectivity, transparency and easy access to finance to all SMMEs. MFIs have alleviated abject poverty by lending out money needed by start-up SMMEs in South Africa, Nigeria, Kenya and Ethiopia. Microfinance agencies in South Africa were the best, followed 


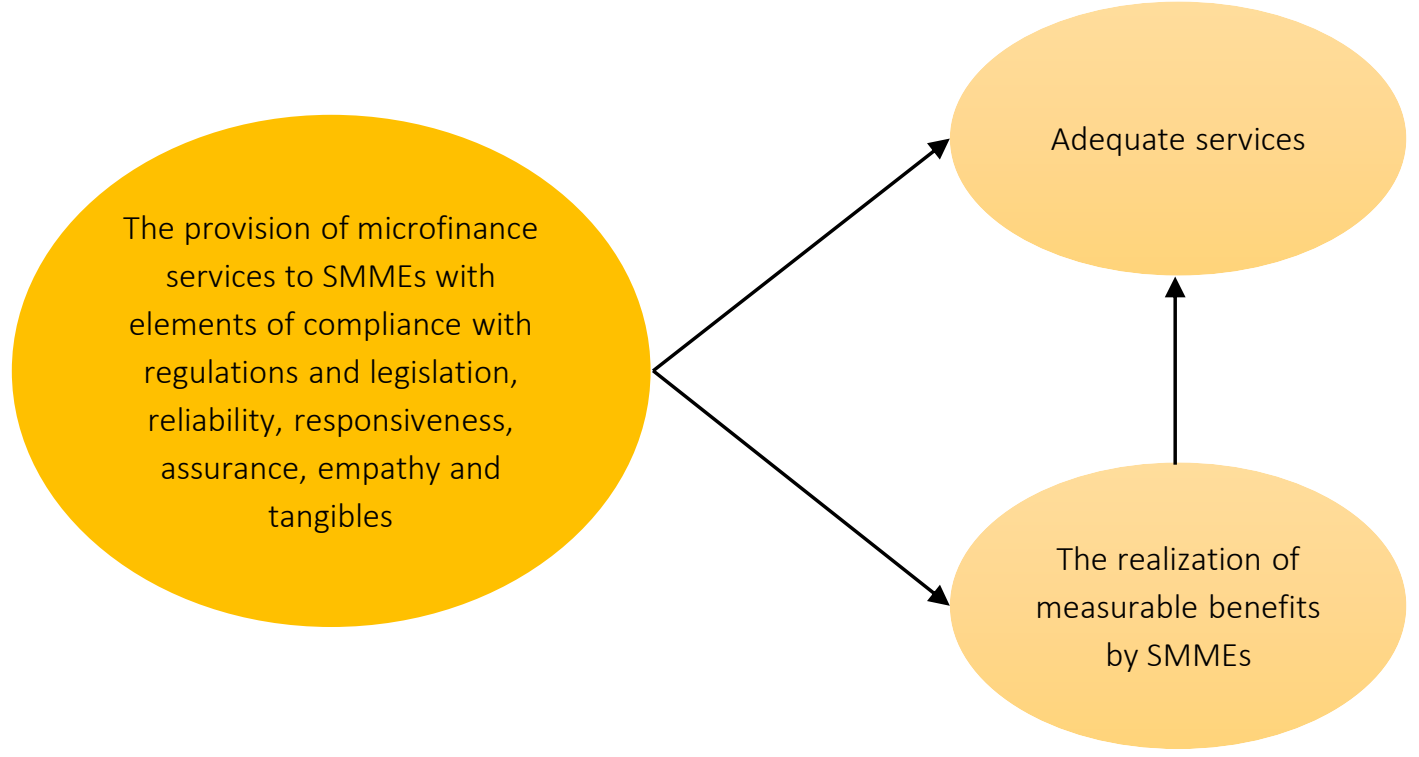

Figure 1. Framework for improved services to SMMEs by microfinance institutions

by Nigerian, Kenyan and Ethiopian microfinance agencies. Microfinance agencies in Ethiopia had the lowest capacity in comparison with agencies in South Africa, Nigeria and Kenya. Lack of capacity in respect of financial capital was a major obstacle in Nigeria, Kenya and Ethiopia. The results confirm the importance of efficient microfinance services as a means of reducing poverty and promoting profitability in SMMEs. The results also show that microfinance agencies often lack resources for providing loans to SMMEs at more affordable rates. The study has shown that microfinance regulations and guidelines are often disregarded by microfinance agencies, as well as SMMEs.

The key mandate of MFIs is to give out small loans to SMMEs so that they could meet their operational and business related needs conveniently.
SMMEs need financial assistance that comes with reasonable interest rates and minimal bureaucracy (Addae-Korankye, 2014). Figure 1 shows a suitable framework of study.

Microfinance agencies have successfully alleviated poverty in all Sub-Saharan African countries by providing loan services to SMMEs. Some of the key challenges for microcredit are lack of lending capacity and political interference in MFI institutions. A framework is vital for ensuring value for money. In this regard, the ability of microfinance institutions to respect and abide by the relevant regulations, guidelines and legislation in South Africa, Nigeria, Kenya and Ethiopia is critically important. Operators of SMMEs need speedy, highly efficient, reliable, affordable and transparent loan services.

\section{CONCLUSION}

The study has shown that microfinance institutions render services that are highly demanded by businesses in all four African countries in the study (South Africa, Nigeria, Kenya and Ethiopia). Everything considered, $21 \%$ of the 401 SMMEs in the study were satisfied with the ease of securing loans from microfinance institutions, whereas the remaining 79\% of SMMEs were not. The study has shown that microfinance institutions in all four countries lack financial capacity for meeting demands for loans from SMMEs, and that they require collaterals for extending loans to businesses. Regulations and guidelines set out by central banks are not adhered to sufficiently in all four countries. Loan repayment conditions are quite stringent in all four countries. Ease of access to microfinance loans was easiest in South Africa in comparison with Nigeria, Kenya and Ethiopia. The implication of study is that there is a need 
for the governments of South Africa, Nigeria, Kenya and Ethiopia to build capacity into microfinance institutions, and that services provided by microfinance institutions should be monitored and evaluated by central banks as a means of ensuring the quality of microfinance services that are provided to SMMMEs. The study has a minor limitation. Due to shortage of resources, data were collected from microfinance institutions only. There is a need for further research by collecting empirical data from commercial banks on loans provided to SMMEs.

\section{REFERENCES}

1. Abate, G. T., Borzaga, C., \& Getnet, K. (2014). Cost-Efficiency and Outreach of Microfinance Institutions: Trade-offs and the Role of Ownership. Journal of International Development, 26(6), 923-932. https://doi.org/10.1002/ jid.2981

2. Ayele, G. T. (2015). Microfinance Institutions in Ethiopia, Kenya and Uganda: Loan Outreach to the Poor and the Quest for Financial Viability. African Development Review, 27(2), 117-129. https://doi. org/10.1111/1467-8268.12128

3. Bassem, B. S. (2014). Total Factor Productivity Change of MENA Microfinance Institutions: A Malmquist Productivity Index Approach. Economic Modelling, 39(1), 182-189. https://doi.org/10.1016/j.econmod.2014.02.035

4. Banerjee, A., Duflo, E., Goldberg, N., Karlan, D., Osei, R., Pariente W., Shapiro, J., Thuysbaert, B., \& Udry, C. (2015). A Multifaceted Program Causes Lasting Progress for the Very Poor: Evidence from Six Countries. Science, 348(6236), 1260799. https://doi.org/10.1126/ science.1260799

5. Banerjee, A., Karlan, D., \& Zinman, J. (2015). Six Randomized Evaluations of Microcredit: Introduction and Further Steps. American Economic Journal: Applied Economics, 7(1), 1-21. Retrieved from https://economics.mit.edu/files/10475

6. Barry, T. A., \& Tacneng, R. (2014) The impact of Governance and Institutional Quality on MFI Outreach and Financial Performance in Sub-Saharan Africa. World Development, 58(1), 1-20. Retrieved from https://ideas. repec.org/a/eee/wdevel/v58y2014icp1-20.html
7. Bazilian, M., Nakhooda, S., \& Van de Graaf, T. (2014). Energy Governance and Poverty. Energy Research \& Social Science, 1(1), 217-225. Retrieved from https://biblio.ugent.be/publication/4370842

8. Biosca, O., Lenton, P., \& Mosley, P. (2014). Microfinance Non-Financial Services as a Competitive Advantage: The Mexican Case. Strategic Change, 23(7-8), 507-511. https://doi. org/10.1002/jsc. 1992

9. Brautigam, D., \& Gallagher, K. P. (2014). Bartering Globalization: China's Commodity-Backed Finance in Africa and Latin America. Global Policy, 5(3), 346352. https://doi.org/10.1111/17585899.12138

10. Bruton, G. D., Ketchen, J. R., \& Ireland, R. D. (2013). Entrepreneurship as a Solution to Poverty. Journal of Business Venturing, 28(6), 683-689. https://doi.org/10.1016/j.jbusvent.2013.05.002

11. Chakrabarty, S., \& Bass, A. E. (2013). Encouraging Entrepreneurship: Microfinance, Knowledge Support, and the Costs of Operating in Institutional Voids. Thunderbird International Business Review, 55(5), 545-562. Retrieved from https://pdfs.semanticscholar. org/2d4e/b369648675dd01534408 5ea7b6166844c739.pdf

12. Chatterjee, S., \& Hadi, A. S. (2015). Regression Analysis by Example. New York: John Wiley \& Sons.

13. Cramm, J. M., \& Nieboer, A. P. (2011). The Influence of Social Capital and Socio-Economic Conditions on Self-Rated Health Among Residents of an Economically and Health-
Deprived South African township. International Journal for Equity in Health, 10(1), 51-59. https://doi. org/10.1186/1475-9276-10-51

14. Crane, A., \& Matten, D. (2016). Business Ethics: Managing Corporate Citizenship and Sustainability in the Age of Globalization. Oxford: Oxford University Press. Retrieved from https:/global.oup.com/ ukhe/product/business-ethics-9780199697311

15. Defusco, R. A., McLeavey, D. W., Pinto, J. E., Anson, M. J., \& Bunkle, D. E. (2015). Quantitative Investment Analysis. New York: John Wiley \& Sons. Retrieved from https://www.wiley.com/en.../ Quantitative+Investment+Analysi s\%2C+3rd+Edition-p-97...

16. Edoho, F. M. (2015).

Entrepreneurialism: Africa in Transition. African Journal of Economic and Management Studies, 6(2), 127-147. Retrieved from https://ideas.repec.org/s/ eme/ajempp.html

17. Henrekson, M. (2014) Entrepreneurship, Innovation, and Human Flourishing. Small Business Economics, 43(3), 511528. Retrieved from www.ifn.se/ wfiles/wp/wp999.pdf

18. Filmer, D., \& Fox, L. (2014). Youth Employment in Sub-Saharan Africa. Washington DC: World Bank Publications. Retrieved from https://elibrary.worldbank. org/doi/pdf/10.1596/978-1-46480107-5

19. Fosu, A. K. (2015). Growth and Institutions in African Development. New York: Routledge. Retrieved from https:// mpra.ub.uni-muenchen.de/68656/ 
20. Guerin, I., Morvant-Roux, S., \& Villarreal, M. (2013). Microfinance, Debt and Over-Indebtedness: Juggling with Money. New York: Routledge. Retrieved from https:// www.routledge.com/Microfinance-Debt-and-Over-Indebtedness-Juggling-with-...

21. Hair, J. F., Black, W. C., Babin, B. J., \& Anderson, R. E. (2010). Multivariate Data Analysis: A Global Perspective. London: Pearson. Retrieved from www.scirp.org/ (S(351jmbntvnsjt1aadkposzje))/ reference/ReferencesPapers.aspx?...

22. Haneef, M. A., Pramanik, A. H., Mahommed, M. O., \& Muhammad, A. D. (2014). Integrated Waqf Based Islamic Microfinance Model (IWIMM) for Poverty Alleviation in OIC Member Countries. Middle-East Journal of Scientific Research, 19(2), 286-298. Retrieved from www.idosi.org/mejsr/mejsr19\%282\%2914/20.pdf

23. Jaffari, S. I. A., Saleem, S., Abideen, Z. U., Kaleem, M. M., Malik, N., \& Raza, M. (2011). An Examination of Challenges and Prospects of Microfinance Sector of Pakistan. Europe Journal of Economics, Finance and Administrative Studies, 31(1), 146-159. Retrieved from https://ibtra.com/pdf/journal/ v11_n2_article6.pdf

24. Julian, S. D., \& Ofori-Dankwa, J. (2013). Financial Resource Availability and Corporate Social Responsibility Expenditures in a Sub-Saharan Economy: The Institutional Difference Hypothesis. Strategic Management Journal, 34(11), 1314-1330. https:// doi.org/10.1002/smj.2070

25. Kemboi, J. K., \& Tarus, D. K. (2013). Macroeconomic Determinants of Stock Market Development in Emerging Markets: Evidence from Kenya. Review of Quantitative Finance and Accounting, 4(9), 84-95. Retrieved from https://www.iiste. org/Journals/index.php/RJFA/ article/view/2124

26. Khale, S., \& Worku, Z. (2015). Benefits of Good Corporate Governance Principles: A Study of the City of Tshwane, South Africa. Journal of Corporate Governance and Control, 13(1), 753-770. http:// dx.doi.org/10.22495/cocv13i1c9p1

27. Kolk, A., Rivera-Santos, M., \& Rufin, C. (2014). Reviewing a Decade of Research on the Base/ Bottom of the Pyramid (BOP) Concept. Business \& Society, 53(3), 338-377. https://doi.org/10.1177\%2F0007650312474928

28. Mersland, R., \& Strom, O. (2014). Microfinance Institutions: Financial and Social Performance. New York: Springer. Retrieved from https://www.palgrave.com/ gp/book/9781137399656

29. Mori, N., Golesorkhi, S., Randoy, T., \& Hermes, N. (2015). Board Composition and Outreach Performance of Microfinance Institutions: Evidence from East Africa. Strategic Change, 24(1), 99-113. https://doi.org/10.1002/ jsc. 2000

30. Musamali, M. M., \& Tarus, D. K. (2013). Does Firm Profile Influence Financial Access Among Small and Medium Enterprises in Kenya? Asian Economic and Financial Review, 3(6), 714-721. Retrieved from https://ideas.repec. org/a/asi/aeafrj/2013p714-723. html

31. Nega, B., \& Schneider, G. (2014). NGOs, the State, and Development in Africa. Review of Social Economy, 72(4), 485-503. https://doi.org/10.1080/00346764. 2014.958901

32. Newman, A., Schwarz, S., \& Borgia, D. (2014). How Does Microfinance Enhance Entrepreneurial Outcomes in Emerging Economies? The Mediating Mechanisms of Psychological and Social Capital. International Small Business Journal, 32(2), 158-179. https://doi.org/10.1177\%2F0266242613485611

33. Okpara, G. C. (2010). Microfinance Banks and Poverty Alleviation in Nigeria. Journal of Sustainable Development in Africa, 12(6), 177-191. Retrieved from www.diva-portal.org/smash/get/ diva2:1103573/FULLTEXT01.pdf
34. Otieno, O. A., \& Moronge, M. (2014). Influence of Product Diversification on the Financial Performance of Selected Commercial Banks in Kenya. European Journal of Business Management, 1(11), 336-341.

35. Oni, E. O. (2012). Assessment of the Contribution of Micro Finance Institutions (MFIs) to Sustainable Growth of Small and Medium Scale Enterprises (SMEs) in Nigeria. Interdisciplinary Journal of Contemporary Research in Business, 3(9), 2-6. Retrieved from https://journal-archieves14. webs.com/1099-1110.pdf

36. Page, J., \& Soderbom, M. (2015). Is Small Beautiful? Small Enterprise, Aid and Employment in Africa. African Development Review, 27(S1), 44-55. https://doi. org/10.1111/1467-8268.12138

37. Rolffs, P., Ockwell, D., \& Byrne, R. (2015). Beyond Technology and Finance: Pay-as-you-go Sustainable Energy Access and Theories of Social Change. Environment and Planning, 47(12), 2609-2627. https://doi.org/10.1177\%2F0308518X15615368

38. Rose-Ackerman, S., \& Palifka, B. J. (2016). Corruption and Government: Causes, Consequences, and Reform. Cambridge: Cambridge University Press. Retrieved from https://onlinelibrary.wiley.com/doi/abs/10.1111/ gove. 12273

39. Rottenburg, R., Merry S. E., Park, S. J., \& Mugler, J. (2015). The World of Indicators: The Making of Governmental Knowledge Through Quantification. London: Cambridge University Press. Retrieved from https://books.google.co.za/ books?isbn $=3319627074$

40. Schwittay, A. F. (2014). Making Poverty into a Financial Problem: From Global Poverty Lines to Kiva. Journal of International Development, 26(4), 508-519. https://doi.org/10.1002/jid.2966

41. Segun, K. R. S., \& Anjugam, M. (2013). Measuring the Efficiency of Sub-Saharan Africa's Microfinance Institutions and its Drivers. Annals of Public and 
Cooperative Economics, 84(4), 399-422. Retrieved from https:// onlinelibrary.wiley.com/doi/ abs/10.1111/apce.12021

42. Shisia, A., Marangu, W. N., \& Omwario, B. (2014). Assessment of the Contribution of Credit Reference Bureau Regulation Towards Mitigating Credit Risks in the Kenya's Banking Industry. European Journal of Business and Management, 6(14), 1-8. Retrieved from https://www.iiste.org/Journals/index.php/EJBM/article/ download/14770/15264/

43. Sila, A. K. (2014). Relationship Between Training and Performance: A Case Study of Kenya Women Finance Trust Eastern Nyanza Region, Kenya. European Journal of Business and Social Sciences, 3(1), 95-117. Retrieved from https://www. semanticscholar.org/paper/ RELATIONSHIP-BETWEEN-
TRAINING-AND-PERFORMANCE-\%3A-A-\%2C-SILA c13b0e6817ca216e2ccb30d0cdfdc252b8dcd104

44. Siwale, J. N., \& Ritchie, J. (2012). Disclosing the Loan Officer's Role in Microfinance Development. International Small Business Journal, 30(4), 432-450. https://doi.org/10.1177\%2F0266242610373687

45. Taiwo, J. N., Onasanya, A., Yewande, A., Edwin, M., \& Benson, K. N. (2016). The Role of Microfinance Institutions in Financing Small Businesses. Journal of Internet Banking and Commerce, 21(1), 21-32. Retrieved from http://www.icommercecentral.com/open-access/the-roleof-microfinance-institutionsin-financing-small-businesses. php?aid $=70480$

46. Wijesiri, M., \& Meoli, M. (2015). Productivity Change of Microfinance Institutions in Kenya: A Bootstrap Malmquist Approach. Journal of Retailing and Consumer Services, 25(1), 115-121. http:// dx.doi.org/10.1016/j.jretconser.2015.04.004

47. Worku, E. B., \& Worku, Z. B. (2008). Factors That Affect the Long Term Survival of Micro, Small and Medium Enterprises in Ethiopia. South African Journal of Economics, 76(3), 548-568. Retrieved from https://onlinelibrary.wiley.com/doi/abs/10.1111/ j.1813-6982.2008.00207.x

48. Worku, Z. (2016). Barriers to the Growth of Small, Micro and Medium-Sized Business Enterprises in the Vaal Triangle Region of South Africa. African Journal of Science, Technology, Innovation and Development, 8(2), 134-141. https://doi.org/10.1080/ 20421338.2015.1128135 